\title{
Effects of Testosterone Replacement on Insulin Sensitivity, Blood Glucose, Serum Lipids and Vitamin D Concentration in a Rat Model of Andropause
}

\author{
Mohamad Yosof Rezk ${ }^{1}$, Hany Ahmed Elkatawy ${ }^{1}$, Ahmed Mohamed Shata ${ }^{2}$, Khalid Mohammad Mohany ${ }^{3}$ \\ ${ }^{1}$ Medical Physiology Department, Faculty of Medicine, Zagazig University, Zagazig, Egypt \\ ${ }^{2}$ Department of Clinical Pharmacology, Mansoura University, Mansoura, Egypt \\ ${ }^{3}$ Biochemistry Department, Faculty of Medicine, Assuit University, Assuit, Egypt
}

Email address:

myr777777777@yahoo.com (M. Y. Rezk), hkataway@gmail.com (H. A. Elkatawy), ahmedmhes@mans.edu.eg (A. M. Shata), khalidmohany9@gmail.com (K. M. Mohany)

\section{To cite this article:}

Mohamad Yosof Rezk, Hany Ahmed Elkatawy, Ahmed Mohamed Shata, Khalid Mohammad Mohany. Effects of Testosterone Replacement on Insulin Sensitivity, Blood Glucose, Serum Lipids and Vitamin D Concentration in a Rat Model of Andropause. International Journal of Clinical and Experimental Medical Sciences. Vol. 3, No. 3, 2017, pp. 30-35. doi: 10.11648/j.ijcems.20170303.11

Received: April 29, 2017; Accepted: May 9, 2017; Published: May 19, 2017

\begin{abstract}
Background: Testosterone facilitates various metabolic processes in the bones, muscles, bone marrow, brain and immune system. Testosterone deficiency may contribute to cardiovascular diseases, central obesity and metabolic dysfunction. Aim: to investigate the effects of testosterone deficiency on blood glucose levels, insulin sensitivity, vitamin D, Homeostatic model assessment of insulin resistance (HOMA-IR), Homeostatic model assessment for beta function (HOMA-IR) and serum lipids in rat models of andropause. Methods, 48 male rats divided into 4 equal groups ( $\mathrm{n}=12$ /group); a) Control (C) group. b) Orchiectomy $(\mathrm{O})$ group underwent bilateral removal of the testicles. c) Orchiectomy and treated $(\mathrm{O}+\mathrm{T})$ group given daily IM testosterone replacement therapy for 7 days, d) Sham and treated $(\mathrm{Sh}+\mathrm{T})$ group in which sham operated rats were given the same daily dose of $\mathrm{T}$ as $\mathrm{O}+\mathrm{T}$ group for 7 days. Results: we found that plasma glucose concentration increased significantly $(\mathrm{P}<0.001)$ in $\mathrm{O}$ group. This increase was corrected by testosterone injection in $\mathrm{O}+\mathrm{T}$ group. In $(\mathrm{Sh}+\mathrm{T})$ group, there is a significant reduction in serum glucose $(\mathrm{P}<0.001)$. We also found that insulin level reduced significantly $(\mathrm{P}<0.001)$ in $\mathrm{O}$ group. This reduction in insulin level was corrected by testosterone. In ( $\mathrm{Sh}+\mathrm{T})$ group, insulin level increased significantly. 25-OHVD3 was reduced significantly $(\mathrm{P}<0.05)$ in $\mathrm{O}$ group and increased significantly in $\mathrm{O}+\mathrm{T}$ group. HOMA-IR level decreased significantly $(\mathrm{P}<0.001)$ and this reduction was corrected by Testosterone. HOMA- $\beta$ reduced significantly $(\mathrm{P}<0.001)$ and this reduction was corrected by Testosterone in $\mathrm{O}+\mathrm{T}$ group. In SH group, there is a marked increase in HOMA- $\beta$. We also found insignificant differences between the four groups in serum triglycerides. However, we found very highly significant differences in total cholesterol, LDL and VLDL between $\mathrm{C}$ group and $\mathrm{O}$ group and very highly significant differences between $\mathrm{O}+\mathrm{T}$ group and $\mathrm{Sh}+\mathrm{T}$ group in comparison with $\mathrm{O}$ group. We also found significant differences in serum HDL-c in (O) group in comparison with (C) group and between $\mathrm{O}+\mathrm{T}$ and $\mathrm{Sh}+\mathrm{T}$ groups in comparison with $\mathrm{O}$ group. In conclusion, we found significant reduction in 25-OH(VD), Testosterone, Insulin, HOMA-IR and HOMA-B and significant increase in glucose serum levels in $\mathrm{O}$ group and these changes were corrected by Testosterone injection in $\mathrm{O}+\mathrm{T}$ group. We also found insignificant differences between the four groups in serum triglycerides. However, we found highly significant differences in total cholesterol, LDL, HDL-c and VLDL between $\mathrm{C}$ group and $\mathrm{O}$ group and very highly significant differences between $\mathrm{O}+\mathrm{T}$ group and $\mathrm{Sh}+\mathrm{T}$ group in comparison with $\mathrm{O}$ group.
\end{abstract}

Keywords: Testosterone, Orchiectomized, Insulin, HOMA-IR, HOMA-B, Glucose 


\section{Introduction}

Testosterone is responsible for sexual desire, erection and secondary sex characteristics. Testosterone facilitates various metabolic processes in the bones, muscles, bone marrow, brain and immune system. Therefore, testosterone deficiency leads to metabolic dysfunctions ${ }^{1}$.

In men, $80 \%$ of total testosterone binds to sex hormone binding globulin and acts as a reserve source. Free testosterone and albumin bound testosterone are biologically active representing $20 \%$ of total testosterone ${ }^{2,3}$.

Andropause is a prevalent and serious aging related problem. The gradual decline of testosterone levels with aging may be due to reduction of Leydig cell mass, testicular circulation, hypothalamic GnRH and pituitary gonadotropins 4,5 . Decreased androgen levels associated with aging is referred as Late-onset hypogonadism. It is manifested by (i) somatovegetative conditions, including fatigue, insomnia, osteopenia, sarcopenia and visceral obesity, (ii) psychological conditions, including disturbed sense of well-being, mood disorders and anxiety and (iii) sexual conditions, including erectile dysfunction and decreased libido ${ }^{6-8}$.

Testosterone deficiency may contribute to cardiovascular diseases, central obesity and metabolic dysfunction and its deficiency promoted atherosclerosis by changing lipid metabolism 9. Visceral obesity leads to gonadotropin suppression and subsequent testosterone deficiency 10. Clinical studies reported that testosterone levels inversely correlated with total cholesterol and LDL cholesterol levels ${ }^{11-13}$. In addition, animal studies demonstrated highly elevated cholesterol levels in testosterone-deficient male mice ${ }^{14,15}$. These findings suggested that testosterone serves a valuable role in regulating serum lipids. However, other controversial studies reported the reverse and some of them reported insignificant effects of testosterone ${ }^{16-}{ }^{18}$. So, for this controversy, we conducted this study to elucidate the effect of cholesterol on lipid profile.

Therefore, this study is carried out to evaluate the effects of testosterone deficiency on blood glucose levels, insulin sensitivity, HOMA-IR, HOMA-B, serum lipids and vitamin $\mathrm{D}$ concentration in rat models of andropause.

\section{Methods}

Animals: A total of 48 male Albino rats (250-300 g) from the experimental animal center in the College of Pharmacy Zagazig University were used in this study, between June and August 2016. Methods in this study are approved by the National Medical Ethics Committee in faculty of medicine of Zagazig University (Institutional Review Board, IRB). Rats were fed on a normal diet with free access to water, at comfortable temperature, in addition to $12 \mathrm{~h}$ light/dark cycle and hygienic issues were considered. Rats were kept one week for acclimatization then randomly divided into 4 equal groups ( $\mathrm{n}=12$ /group); a) Control (C) group which underwent sham operation, in addition to intramuscular (IM) injection with $0.2 \mathrm{ml}$ of normal saline. b) Orchiectomy (O) group in which all rats were surgically managed by bilateral removal of the testicles in addition to IM injection $0.2 \mathrm{ml}$ of normal saline. c) Orchiectomy and treated $(\mathrm{O}+\mathrm{T})$ group in which orchiectomized rats were further given daily IM testosterone replacement therapy for 7 days. d) Sham and treated (Sh+T) group in which sham operated rats were given the same daily dose of $\mathrm{T}$ as $\mathrm{O}+\mathrm{T}$ group for 7 days.

Chemicals: ketamine/xylazine mixture and Testosterone undecanoate purchased from Sigma Chemicals co. Cairo Egypt.

Surgical procedure: Rats were generally anesthetized via intraperitoneal injection of ketamine/xylazine mixture $\left(100 / 10 \mathrm{mg} / \mathrm{kg}\right.$, respectively) ${ }^{19}$ that produces a good anesthesia, and muscle relaxation for $20 \mathrm{~min}$ in addition to postoperative analgesia. Anesthetized animals were placed in the supine position, fixed over a sterile small animal operating theatre. Before skin incision, disinfection of the testicular area with iodized alcohol was done. The sham operation was performed through a midline incision in the ventral aspect of the scrotum then dissection of subcutaneous tissues until exploration of testes and suture of the skin. In orchiectomized rats, tunicae were opened, testes were ligated with 3-0 Vicryl placed around the lower end of the spermatic cord then the testes were removed after cutting between two ligations. Subsequently, the testicular skin was sutured and a local antibiotic ointment was applied over the sutures ${ }^{20}$. Animals were left for 2 weeks after surgery for complete healing of wounds and development of andropause ${ }^{21}$.

Testosterone hormone replacement therapy: The $\mathrm{O}+\mathrm{T}$ and $\mathrm{Sh}+\mathrm{T}$ groups were IM injected with $\mathrm{T}$ undecanoate (100 $\mathrm{mg} / \mathrm{kg}$ ) for 1 week after castration, while the other groups with equal volume of $0.9 \%$ normal saline instead ${ }^{22}$.

Serology: Later on, all rats were euthanized and about 6 $\mathrm{mL}$ of blood was collected via cardiac puncture. The blood was put in green-topped mini collection tubes and centrifuged (Sigma Aldrich Eppendorf® Centrifuge 5702) at $12000 \mathrm{rpm}$ for 12 minutes at $4^{\circ} \mathrm{C}$, and the plasma was collected and stored at $-80^{\circ} \mathrm{C}$. Assays for testosterone was done by ELISA kits ${ }^{23}$, catalogue number MBS026898 (Mybiosource, USA). 25-OHVD3 was also measured by rat ELISA kits ${ }^{24}$ catalogue no MBS288530 (Mybiosource USA). Furthermore, rat insulin ELISA kit (MBS724709, Mybiosource USA) was used to measure the insulin level, while plasma glucose concentration was assessed by the spectrophotometric method ${ }^{25}$. Additionally, Homeostatic model assessment for insulin resistance (HOMA-IR) and Homeostatic model assessment for beta function (HOMA-IR) were calculated ${ }^{26}$. Serum high density lipoprotein (HDL) was estimated by the method of Warnick ${ }^{27}$. Total cholesterol $(\mathrm{CH})$ and triglycerides (TG) were estimated by the methods of Siedel et al. ${ }^{28}$ and Foster and Dunn ${ }^{29}$, respectively. Low density lipoprotein (LDL) and very low density lipoprotein (VLDL) were calculated by Friedwald's formula ${ }^{30}$.

Statistical analysis: The SPSS, version 24 for Windows (SPSS Inc. Chicago, IL, USA), was used. The data were presented as the mean \pm SD. An ANOVA with a post hoc test was used to analyze the differences in multiple comparisons. 
Pearson correlation coefficient was also used to test the

considered to be significant. relationships among the study variables. $\mathrm{P}$ values $<0.05$ were

\section{Results}

Table 1. Biochemical parameters measured for all studied groups.

\begin{tabular}{|c|c|c|c|c|}
\hline \multirow{2}{*}{ Studied parameters } & Control & Orchiectomy & Orchiectomy treated & Sham \& treated \\
\hline & $n=12$ & $n=12$ & $\mathrm{n}=12$ & $\mathrm{n}=12$ \\
\hline 25(OH)-VD (ng/ml) & $33.22 \pm 7.74$ & $\begin{array}{l}15.00 \pm 2.38 \\
\mathrm{P}<0.05^{\mathrm{a}}\end{array}$ & $\begin{array}{l}73.19 \pm 4.45 \\
\mathrm{P}<0.001^{\mathrm{a}} \\
\mathrm{P}<0.001^{\mathrm{b}}\end{array}$ & $\begin{array}{l}74.40 \pm 10.25 \\
\mathrm{P}<0.001^{\mathrm{a}} \\
\mathrm{P}>0.05^{\mathrm{c}}\end{array}$ \\
\hline Testosterone (ng/ml) & $7.53 \pm 1.38$ & $\begin{array}{l}0.91 \pm 0.35 \\
\mathrm{P}<0.001^{\mathrm{a}}\end{array}$ & $\begin{array}{l}2.94 \pm 0.93 \\
\mathrm{P}<0.001^{\mathrm{a}} \\
\mathrm{P}<0.001^{\mathrm{b}}\end{array}$ & $\begin{array}{l}16.01 \pm 2.86 \\
\mathrm{P}<0.001^{\mathrm{a}} \\
\mathrm{P}<0.001^{\mathrm{c}}\end{array}$ \\
\hline Glucose (mg/dl) & $95.79 \pm 4.55$ & $\begin{array}{l}123.92 \pm 5.90 \\
\mathrm{P}<0.001^{\mathrm{a}}\end{array}$ & $\begin{array}{l}91.89 \pm 9.85 \\
\mathrm{P}>0.05^{\mathrm{a}} \\
\mathrm{P}<0.001^{\mathrm{b}}\end{array}$ & $\begin{array}{l}64.09 \pm 8.45 \\
\mathrm{P}<0.001^{\mathrm{a}} \\
\mathrm{P}<0.001^{\mathrm{c}}\end{array}$ \\
\hline Insulin (mIU/ml) & $8.85 \pm 0.09$ & $\begin{array}{l}4.55 \pm 0.95 \\
\mathrm{P}<0.001^{\mathrm{a}}\end{array}$ & $\begin{array}{l}8.89 \pm 0.08 \\
\mathrm{P}>0.05^{\mathrm{a}} \\
\mathrm{P}<0.001^{\mathrm{b}}\end{array}$ & $\begin{array}{l}10.36 \pm 1.54 \\
\mathrm{P}<0.05^{\mathrm{a}} \\
\mathrm{P}<0.001^{\mathrm{c}}\end{array}$ \\
\hline HOMA-IR & $2.09 \pm 0.09$ & $\begin{array}{l}1.44 \pm 0.24 \\
\mathrm{P}<0.001^{\mathrm{a}}\end{array}$ & $\begin{array}{l}2.02 \pm 0.21 \\
\mathrm{P}>0.05^{\mathrm{a}} \\
\mathrm{P}<0.001^{\mathrm{b}}\end{array}$ & $\begin{array}{l}1.23 \pm 0.15 \\
\mathrm{P}<0.001^{\mathrm{a}} \\
\mathrm{P}<0.001^{\mathrm{c}}\end{array}$ \\
\hline НОМА- $\beta$ & $99.06 \pm 17.11$ & $\begin{array}{l}27.08 \pm 6.60 \\
\mathrm{P}>0.05^{\mathrm{a}}\end{array}$ & $\begin{array}{l}121.88 \pm 41.64 \\
\mathrm{P}>0.05^{\mathrm{c}} \\
\mathrm{P}>0.05^{\mathrm{c}}\end{array}$ & $\begin{array}{l}810.69 \pm 251.50 \\
\mathrm{P}<0.001^{\mathrm{a}} \\
\mathrm{P}<0.001^{\mathrm{c}}\end{array}$ \\
\hline
\end{tabular}

$\mathrm{a}=p$-value of significance versus control group, $\mathrm{b}=p$-value of significance versus orchiectomy group, $\mathrm{c}=p$-value of significance versus orchiectomy treated group.

Table 2. Serum Lipids (Mean $\pm S D)$.

\begin{tabular}{llll}
\hline Studied parameters $(\mathbf{m M})$ & Control & Orchiectomy & Orchiectomy treated \\
\hline Triglyceride & $1.08 \pm 0.19$ & $1.16 \pm 0.46$ & $1.09 \pm 0.23$ \\
Total Cholesterol & $0.98 \pm 0.09$ & $1.89 \pm 0.23^{* * * a}$ & $0.99 \pm 0.13^{* * * \mathrm{~b}}$ \\
HDL-c & $1.12 \pm 0.30$ & $0.91 \pm 0.16^{* \mathrm{a}}$ & $1.11 \pm 0.30$ \\
LDL & $49.64 \pm 1.82$ & $52.74 \pm 2.32^{* * \mathrm{a}}$ & $0.91 \pm 0.53$ \\
VLDL & $15.22 \pm 0.48$ & $17.12 \pm 0.36^{* * *_{\mathrm{a}}}$ & $1.24 \pm 1.12^{* * \mathrm{~b}}$ \\
\hline
\end{tabular}

HDL-c, high-density lipoprotein-cholesterol;

LDL, Low-density lipoprotein

VLDL, Very-Low-density lipoprotein-cholesterol

$* a=$ significant in comparison with control group

$*_{\mathrm{a}}=$ significant in comparison with Orchiectomized group

\section{Discussion}

Testosterone facilitates various metabolic processes in the bones, muscles, bone marrow, brain and immune system. Testosterone deficiency may contribute to cardiovascular diseases, central obesity and metabolic dysfunction? Therefore, this study aims to demonstrate the effects of testosterone deficiency on blood glucose levels, insulin sensitivity, vitamin D and Serum lipids in rat models of andropause.

In our study, we found that plasma glucose concentration increased (from $95.79 \pm 4.55$ to $123.92 \pm 5.90$ ) significantly $(\mathrm{P}<0.001)$ in orchiectomized rats in comparison with the control group. This increase was corrected $(91.89 \pm 9.85)$ by testosterone injection in Orchiectomy treated group. In sham treated group, there is a significant reduction in serum glucose $(64.09 \pm 8.45) \quad(\mathrm{P}<0.001)$. These findings were in agreement with RAO PM., et al ${ }^{10}$ who found that testosterone stimulates glucose uptake, glycolytic pathway and oxidative phosphorylation. They reported that testosterone participates in lipid homeostatic mechanisms in many tissues, as liver and adipose tissue.

In the present study, we found that insulin level reduced (from $8.85 \pm 0.09$ to $4.55 \pm 0.95)$ significantly $(\mathrm{P}<0.001)$ in orchiectomized rats in comparison with the control group. This reduction in insulin level was corrected by testosterone $(8.89 \pm 0.08)$ in Orchiectomy treated group. In sham treated group, insulin level increased $(10.36 \pm 1.54)$ significantly in comparison with the last two groups. Our results were in agreement with Zitzmann M. ${ }^{31}$ who reported that testosterone deficiency promoted the development of the metabolic syndrome and it has antagonizing effects on the generation of muscle and visceral adipose tissue.

In our study, we also found that $25-(\mathrm{OH}) \mathrm{D}$ was reduced (from $33.22 \pm 7.74$ to $15.00 \pm 2.38)$ significantly $(\mathrm{P}<0.05)$ in orchiectomized rats. In addition, we found that testosterone increased 25(OH)D significantly (from 15.00 \pm 2.38 to $73.19 \pm 4.45)$ in Orchiectomy treated group. Our findings were in agreement with Zhao et al., ${ }^{32}$ who found that Lower 
25(OH)D concentrations were associated with lower Sex Hormone Binding Globulin (SHBG) levels and higher free testosterone levels in both men and women. However, our results were in controversy with Haymana et al., ${ }^{33}$ who found that $25(\mathrm{OH}) \mathrm{D} 3$ was not significantly changed after testosterone replacement therapy (TRT). This controversy can be explained by species differences as well as short term duration used in the latter study.

In the present study, we found that homeostatic model assessment of insulin resistance (HOMA-IR) levels decreased (from $2.09 \pm 0.09$ to $1.44 \pm 0.24$ ) significantly $(\mathrm{P}<0.001)$ and this reduction was corrected by Testosterone replacement $(2.02 \pm 0.21)$. Our findings are in agreement with Schianca et al., [34] who found that HOMA-IR was related to testosterone and free-testosterone even in patients with normal glucose tolerance. They also reported that at multivariate analysis HOMA-IR was the only variable associated to testosterone $(\mathrm{p}<0.001)$ and free-testosterone $(p<0.05)$ plasma concentration. However, our results were in controversy with Haymana et al., ${ }^{33}$ who found that HOMAIR levels were not significantly changed after a short-term testosterone replacement therapy (TRT). This controversy can be explained by species differences as well as short-term duration used in the latter study.

We also found that HOMA- $\beta$ reduced (from $99.06 \pm 17.11$ to $27.08 \pm 6.60)$ significantly $(\mathrm{P}<0.001)$ and this reduction was corrected by Testosterone replacement (121.88土41.64) in orchiectomy treated group. In sham-operated group, there is a marked increase in HOMA- $\beta$ (810.69 \pm 251.50$)$. Our findings are in agreement with Zitzmann $\mathrm{M},{ }^{31}$ who found that testosterone has a protective effect on pancreatic beta cells, this effect exerted by androgen-receptor-mediated mechanisms.

In our study, we also found insignificant differences between the four groups in serum triglycerides. Our finding was in agreement with Christoffersen et al., ${ }^{35}$ who found that triglycerides concentration did not differ significantly between the groups. However, we were in controversy with Richard et al., ${ }^{36}$ who found a decreased TG concentration in castrated rats.

In the present study, we found very highly significant differences in total cholesterol between Control (C) group $(0.98 \pm 0.09)$ and Orchiectomy (O) group (1.89 \pm 0.23$)$ $(\mathrm{P}<0.001)$. In addition, we found very highly significant differences between Orchiectomy treated $(\mathrm{O}+\mathrm{T})$ group $(0.99$ $\pm 0.13) \quad(\mathrm{P}<0.001)$ and Sham treated $(\mathrm{Sh}+\mathrm{T}) \quad(0.96 \pm 0.39)$ group in comparison with Orchiectomy (O) group. Our finding was supported by $\mathrm{Xu}$ et al., ${ }^{37}$ who found that orchiectomy lead to increased total cholesterol levels in rats. However, we are in controversy with Christoffersen et al., ${ }^{35}$ who found insignificant increase in cholesterol concentration in Orchiectomy $(\mathrm{O})$ group. This controversy can be explained by species differences where their study was performed on Sprage Dawly rats and our study on albino rats. In addition, the diets used in their study were not cholesterol enriched.

We also found significant differences in serum high density lipoprotein-cholesterol (HDL-c) between Orchiectomy (O) group $(0.91 \pm 0.16)$ in comparison with
Control (C) group $(1.12 \pm 0.30)$ and $(\mathrm{P}<0.05)$. Also, we found significant differences between Orchiectomy treated $(\mathrm{O}+\mathrm{T})$ $(1.11 \pm 0.23)(\mathrm{P}<0.05)$ and Sham treated $(\mathrm{Sh}+\mathrm{T})(1.26 \pm 0.50)$ groups in comparison with Orchiectomy (O) group $(0.91 \pm 0.16)$. Our results are in agreement with Christoffersen et al., ${ }^{35}$ who found a larger increase in HDL-c in the castrated group.

we found highly significant differences in Low Density Lipoprotein (LDL) between Control (C) group $(49.64 \pm 1.82)$ and Orchiectomy $(\mathrm{O})$ group $(52.74 \pm 2.32)$ $(\mathrm{P}<0.01)$. Also, we found highly significant differences between Orchiectomy treated $(\mathrm{O}+\mathrm{T})$ group $(50.24 \pm 1.12)$ $(\mathrm{P}<0.001)$ and Sham treated $(\mathrm{Sh}+\mathrm{T})(48.64 \pm 1.32)$ group in comparison with Orchiectomy $(\mathrm{O})$ group. Our findings are in agreement with Cai et al., ${ }^{38}$ who found that the levels of total cholesterol and LDL cholesterol are increased significantly by castration.

We also found very highly significant differences in Very Low Density Lipoprotein (VLDL) between Control (C) group $(15.22 \pm 0.48)$ and Orchiectomy (O) group $(17.12 \pm 0.36)(\mathrm{P}<0.001)$. Also, we found highly significant differences between Orchiectomy treated $(\mathrm{O}+\mathrm{T})$ group $(15.93 \pm 0.37) \quad(\mathrm{P}<0.001)$ and Sham treated $\quad(\mathrm{Sh}+\mathrm{T})$ $(12.22 \pm 0.32)$ group in comparison with Orchiectomy $(\mathrm{O})$ group. We are in controversy with Rouver et al., ${ }^{39}$ who found that the concentrations of triglycerides and VLDL were decreased after 15 days of castration.

In conclusion, we found significant reduction in 25OH(VD), Testosterone, Insulin, HOMA-IR and HOMA-B and significant increase in glucose serum levels in orchiectomized rats and these changes were corrected by Testosterone injection. In our study, we also found insignificant differences between the four groups in serum triglycerides. However, we found very highly significant differences in total cholesterol, LDL and VLDL between Control (C) group and Orchiectomy (O) group and very highly significant differences between Orchiectomy treated $(\mathrm{O}+\mathrm{T})$ group and Sham treated $(\mathrm{Sh}+\mathrm{T})$ group in comparison with Orchiectomy $(\mathrm{O})$ group. We also found significant differences in serum HDL-c (O) group in comparison with (C) group. In addition, we found significant differences between $\mathrm{O}+\mathrm{T}$ and $\mathrm{Sh}+\mathrm{T}$ groups in comparison with $\mathrm{O}$ group. Further studies need to investigate the clinical applications of testosterone administration in human.

\section{References}

[1] Bagatell CJ, Bremner WJ. Androgens in men- uses and abuses. N Engl J Med (1996); 334 (11): 707-714.

[2] Lund BC, Bever-Stille KA, and Perry PJ. Testosterone and andropause: the feasibility of testosterone replacement therapy in elderly men. Pharmacotherapy (1999); 19 (8): 951-956.

[3] Nankin HR and Calkins JH. Decreased bioavailable testosterone in aging normal and impotent men. J Clin Endocrinol Metab (1986); 63 (6): 1418-1420. 
[4] Neaves WB, Johnson L, Porter JC, Parker JR CR and Petty CS. Leydig cell numbers, daily sperm production, and serum gonadotropin levels in aging men. J Clin Endocrinol Metab (1984); 59 (4): 756-7663.

[5] Winters SJ and Troen P. Episodic luteinizing hormone (LH) secretion and the response of $\mathrm{LH}$ and follicle-stimulating hormone to LH releasing hormone in aged men: evidence for coexistent primary testicular insufficiency and an impairment in gonadotropin secretion. J Clin Endocrinol Metab. (1982); 55 (3): $560-565$.

[6] Namiki M, Akaza H, Shimazui T, Ito $\mathrm{N}$ and Iwamoto $\mathrm{T}$. Clinical practice manual for late-onset hypogonadism syndrome. Int J Urol (2008); 15: 377-388.

[7] Bhasin S, Cunningham GR, Hayes FJ, Matsumoto AM and Snyder PJ Testosterone therapy in men with androgen deficiency syndromes: an Endocrine Society clinical practice guideline. J Clin Endocrinol Metab (2010); 95: 2536-2559.

[8] Wang C, Nieschlag E, Swerdloff R, Behre HM and Hellstrom WJ. Investigation, treatment, and monitoring of late-onset hypogonadism in males: ISA, ISSAM, EAU, EAA, and ASA recommendations. J Androl (2009); 30: 1-9.

[9] Traish AM and Zitzman N. The complex and multifactorial relationship between testosterone deficiency (TD), obesity and vascular disease. Rev Endocr Metab Disord. (2015); 16 (3): 24968.

[10] Rao PM, Kelly DM and Jones TH. Testosterone and insulin resistance in the metabolic syndrome and T2DM in men. Nat Rev Endocrinol (2013); 9: 479-493.

[11] Isidori AM, Giannetta E, Greco EA, Gianfrilli D, Bonifacio V, Isidori A, et al. Effects of testosterone on body composition, bone metabolism and serum lipid profile in middle-aged men: a meta-analysis. Clin Endocrinol (Oxf). (2005); 63(3):280-93.

[12] Mäkinen JI, Perheentupa A, Irjala K, Pöllänen P, Mäkinen J, Huhtaniemi I, et al. Endogenous testosterone and serum lipids in middle-aged men. Atherosclerosis. (2008); 197(2):688-93.

[13] Zhang N, Zhang H, Zhang X, Zhang B, Wang F, Wang C, et al. The relationship between endogenous testosterone and lipid profile in middle-aged and elderly Chinese men. Eur J Endocrinol. (2014); 170(4):487-94.

[14] Lee CE, Kang JS, Kim KI. Effects of gender, gonadectomy and sex hormones on growth and plasma cholesterol level in rats. Ann Nutr Metab. (2008); 53(1):1-5.

[15] Hatch NW, Srodulski SJ, Chan HW, Zhang X, Tannock LR, King VL. Endogenous androgen deficiency enhances dietinduced hypercholesterolemia and atherosclerosis in lowdensity lipoprotein receptor-deficient mice. Gend Med. (2012); 9(5):319-28.

[16] Haymana C, Sonmez A, Aydogdu A, Tapan S, Basaran Y, Meric C, Baskoy K, Taslipinar A, Yilmaz MI, Azal O. Effect of Testosterone Replacement Therapy on Vitamin D and FGF23 Levels in Congenital Hypogonadism. Endokrynol Pol. (2017); Feb 23

[17] Christoffersen B, Raun K, Svendsen O, Fledelius C, Golozoubova V. Evalution of the castrated male SpragueDawley rat as a model of the metabolic syndrome and type 2 diabetes. Int J Obes (Lond). (2006); 30(8):1288-97.

[18] Richard D, Picard F, Lemieux C, Lalonde J, Samson P,
Deshaies Y. The effects of topiramate and sex hormones on energy balance of male and female rats. Int $\mathrm{J}$ Obes Relat Metab Disord (2002); 26: 344-353.

[19] HEYDARPOUR F, AMINI B, KALANTARI S, ROSTAMI A and HEYDARPOUR P. Determination of sensitivity of male Wistar rats to an equal dose of ketamine/xylazine injection at anesthetic dose in a chronic model of hypernatremia in comparison with control group. Saudi Med J. (2017); 28(10):1485-8.

[20] ROUVER WN, DELGADO NTB, MENEZERS JB, SANTOS RL and MOYSES MR. Testosterone Replacement Therapy Prevents Alterations of Coronary Vascular Reactivity Caused by Hormone Deficiency Induced by Castration. PLoS ONE, 10(8): e0137111. (2015): doi:10.1371/journal.pone.0137111.

[21] Moghadami S, Jahanshahi M, Sepehri H and Amini $H$. Gonadectomy reduces the density of androgen receptorimmunoreactive neurons in male rat's hippocampus: testosterone replacement compensates it. Behav Brain Funct (2016); 28; 12(1): 5.

[22] CUI K, LI R, ZHANG Y, WANG T, WANG SG, YE ZQ, RAO K and LIU JH. Androgen may improve erectile function in castrated rats by regulating the ERK1/2 pathway. Zhonghua Nan Ke Xue (2015); 21(11): 967-72.

[23] SEIFI M, EZZATI B, SAEDI S and HEDAYATI M. The Effect of Ovariectomy and Orchiectomy on Orthodontic Tooth Movement and Root Resorption in Wistar Rats. J Dent (Shiraz) (2015); 16(4): 302-309.

[24] SHUAI B, SHEN L, YANG YP, XIE J, ZHOU PQ, LI H, GUO XF, ZHAO J and WU JL. Effects of Chinese kidneytonifying drugs on bone mineral density (BMD), biomechanics, 25-hydroxy vitamin D3 and 1,25-dihydroxy vitamin D3 of ovariectomized osteoporosis rats. Zhongguo $\mathrm{Gu}$ Shang, (2008); 21(11): 850-3.

[25] CHAIYASUT C, SIVAMARUTHI BS, PWNGKUMSRI N, KEEPAI W, KESIKA P, SAELEE M, TOJING P, SIRILUN S, CHAIYASUT $\mathrm{K}$, PEERAJAN $\mathrm{S}$ and LAILERD $\mathrm{N}$. Germinated Thai Black Rice Extract Protects Experimental Diabetic Rats from Oxidative Stress and Other DiabetesRelated Consequences. Pharmaceuticals (Basel), (2016); 10(1): 1-16.

[26] MARGOLIS LM, RIVAS DA, EZZYAT Y, GAFFNEYSTOMBERG E, YOUNG AJ, McCLUNG JP, FIELDING RA and PASIAKOS SM. Calorie Restricted High Protein Diets Downregulate Lipogenesis and Lower Intrahepatic Triglyceride Concentrations in Male Rats. Nutrients, (2016); 8(9): pii: E571.

[27] Warnick GR, Nguyen T, Alberts AA. Comparison of improved precipitation methods for quantification of highdensity lipoprotein cholesterol. Clin Chem (1985); 31:217.

[28] Siedel J, Hagele EO, Ziegenhorn J., Wahlefeld AW. Reagent for the enzymatic determination of serum total cholesterol with improved lipolytic efficiency. Clin Chem (1983); 29: $1075-1080$

[29] Foster LB, Dunn RT. Stable reagents for determination of serum triglycerides by colorimetric hantzsch condensation method. Clin Chem (1973); 19: 338-340.

[30] Friedwald WT, Levy RI, Fredrickson DS. Estimation of the concentration of LDL-C in plasma without use of the preparative ultracentrifuge. Clin Chem (1972); 18:449-502. 
[31] Zitzmann M. Testosterone deficiency, insulin resistance and the metabolic syndrome. Nat Rev Endocrinol. (2009); 5(12): 673-81.

[32] Zhao D, Ouyang P, de Boer IH, Lutsey PL, Farag YM, Guallar E, Siscovick DS, Post WS, Kalyani RR, Billups KL, Michos ED. Serum vitamin D and sex hormones levels in men and women: The Multi-Ethnic Study of Atherosclerosis (MESA). Maturitas (2017); 96: 95-102.

[33] Haymana C, Sonmez A, Aydogdu A, Tapan S, Basaran Y, Meric C, Baskoy K, Taslipinar A, Yilmaz MI, Azal O. Effect of Testosterone Replacement Therapy on Vitamin D and FGF23 Levels in Congenital Hypogonadism. Endokrynol Pol. (2017); Feb 23.

[34] Schianca GP, Fra GP, Brustia F, Bellan M, Pirovano A, Gualerzi A, Gentile M, Gibbin A, Menegatti M, Bartoli E, Pirisi M. Testosterone Plasma Concentration is Associated with Insulin Resistance in Male Hypertensive Patients. Exp Clin Endocrinol Diabetes; (2017); 125(3): 171-175.

[35] Christoffersen B, Raun K, Svendsen O, Fledelius C, Golozoubova V. Evalution of the castrated male Sprague-
Dawley rat as a model of the metabolic syndrome and type 2 diabetes. Int J Obes (Lond). (2006); 30(8): 1288-97.

[36] Richard D, Picard F, Lemieux C, Lalonde J, Samson P, Deshaies Y. The effects of topiramate and sex hormones on energy balance of male and female rats. Int $\mathrm{J}$ Obes Relat Metab Disord (2002); 26: 344-353.

[37] Xu T, Wang X, Hou S, Zhu J, Zhang X, Huang X. Effect of surgical castration on risk factors for arteriosclerosis of patients with prostate cancer. Chin Med J (2002); 115: 13361340.

[38] Cai Z, Xi H, Pan Y, Jiang X, Chen L, Cai Y, Zhu K, Chen C, $\mathrm{Xu} \mathrm{X}$, Chen $\mathrm{M}$. Effect of testosterone deficiency on cholesterol metabolism in pigs fed a high-fat and highcholesterol diet. Lipids Health Dis. (2015); 7; 14:18.

[39] Rouver WN, Delgado NT, Menezes JB, Santos RL, Moyses MR: Testosterone Replacement Therapy Prevents Alterations of Coronary Vascular Reactivity Caused by Hormone Deficiency Induced by Castration. PLoS One. (2015); 31; 10(8): e0137111. 